\title{
Mediator of RNA Polymerase II Transcription Subunit 17
}

National Cancer Institute

\section{Source}

National Cancer Institute. Mediator of RNA Polymerase II Transcription Subunit 17. NCI Thesaurus. Code C28689.

Mediator of RNA polymerase II transcription subunit 17 (651 aa, $73 \mathrm{kDa}$ ) is encoded by the human MED17 gene. This protein is involved in transcriptional activation. 